\title{
Cultivars, Planting Dates, and Row Spacing Effects on Sesame Seed Yield and Mineral Composition
}

\author{
Harbans L. Bhardwaj ${ }^{1}$, Anwar A. Hamama ${ }^{1}$, Mark E. Kraemer ${ }^{1}$ \& D. Ray Langham ${ }^{2}$ \\ ${ }^{1}$ Agricultural Research Station, Virginia State University, Petersburg, Virginia, USA \\ ${ }^{2}$ Sesaco Corporation, San Antonio, Texas, USA \\ Correspondence: Harbans L. Bhardwaj, Agricultural Research Station, Virginia State University, Petersburg, \\ Virginia 23806, USA. Tel: 1-804-524-6723. Fax: 1-804-524-5950. E-mail: hbhardwj@vsu.edu
}

Received: June 4, 2014 Accepted: June 20, 2014 Online Published: August 15, 2014

doi:10.5539/jas.v6n9p1 URL: http://dx.doi.org/10.5539/jas.v6n9p1

\begin{abstract}
This study was conducted to determine if sesame (Sesamum indicum L., Pedaliaceae) could be grown in Virginia. Five proprietary sesame cultivars (22K, S26, S28, S30, and S32) were planted on May 23 and June 8 during 2011 and on July 9 and July 17 during 2012 using two row spacings $(37.5$ or $75 \mathrm{~cm})$. Effects of cultivars and row spacings on seed yield, and contents of protein and minerals were, generally, non-significant. Effects of planting dates were significant for most traits under study except for contents of Fe and Al. Contents (averaged over two years, five cultivars, two row spacing, four planting dates, and two years) of protein (\%), P (\%), K (\%), S (\%),

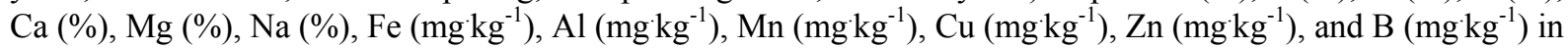
whole seed sesame were 26, 0.67, 0.51, 0.32, 1.12, 0.33, 0.02, 110, 24, 29, 17, 68, and 13, respectively. It was concluded that earlier planting dates using either 37.5 or $75 \mathrm{~cm}$ space between rows are desirable for sesame production in Virginia. Mean seed yield in these studies was $1282 \mathrm{~kg}^{-1} \mathrm{~h}^{-1}$. Highest seed yields were obtained using closer row spacings and early plantings. The results indicated that sesame could be easily produced as a commercial crop in Virginia.
\end{abstract}

Keywords: Sesamum indicum L., protein content, mineral contents, planting dates, row spacings, cultivars

\section{Introduction}

American agriculture has, traditionally, relied upon a few crops and a need exists for diversification of cropping system. The Council for Agricultural Science and Technology (CAST, 2003) lent significant support for the need for crop diversification. The importance of crop diversification in United States is underscored by authorization of the U.S. Congress (Public Law 105-185 passed June 23, 1998) to establish the Thomas Jefferson Agricultural Institute (www.jefforsoninstitute.org) at the University of Missouri. This institute's guiding principle is to help farmers increase their profitability and improve farm stewardship so that family farmers remain a viable and rewarding way of life by focusing on crop diversification. The importance of crop diversification is well documented by the success of Australian and Canadian agriculture. Fletcher (2002) indicated that at least $67 \%$ of the increased value of crop production in Australia over the period 1950-1992 was derived from new crops. Blade (2002) cited the recent successful development of many new crops in Canada such as canola, chickpea, field pea, lentil, mustard, canaryseed, sunflower, and many spice crops. Potential of new legume crops in Virginia has previously been documented (Bhardwaj et al., 1999).

Loss of tobacco as a cash crop has caused a great disturbance in the economies of southern United States including Virginia. At one time, tobacco was the most important crop in Virginia. It contributed \$265,556,000 to the Virginia economy in 1981 as compared to \$71,187,000 in 2006 (Virginia Agricultural Statistics, Richmond, VA). Virginia produced tobacco on 73,340 acres in 1981 as compared to 19,650 acres in 2006. This decline in an important farm commodity calls for research and development for selection/establishment of new crops that could benefit tobacco farmers by raising their farm income and enhancing the overall agricultural economy of Virginia.

This study was conducted to determine if sesame (Sesamum indicum L., Pedaliaceae) could be grown in Virginia. Sesame is one of the oldest crops known to humans. Through the ages, sesame seeds have been a source of food and oil. About $65 \%$ of the annual sesame crop is processed into oil and 35\% is used in food (AgMRC, 2013). 
International demand for sesame continues to increase each year. The world's sesame seed trade recently surpassed one million tons per year and was valued at approximately $\$ 850$ million. In the last 15 years, world trade in sesame has increased by nearly $80 \%$. The United States imports more sesame than it grows. The United States imported sesame seed valued at $\$ 69.9$ million in 2010, which was relatively unchanged from 2009 (AgMRC, 2013). This observation indicates that there is potential for enhancing sesame production in the United States.

One objective of our research was to determine if sesame could be successfully produced in Virginia. Additionally, we were interested in characterization of contents of protein and minerals in sesame seed produced in Virginia in order to address issues related to human nutrition. We have previously studied the contents of sugars in whole sesame seed (Bhardwaj et al., 2014).

\section{Materials and Methods}

\subsection{Plant material and Production}

Five proprietary sesame cultivars (22K, S26, S28, S30, and S32) from Sesaco Corporation (San Antonio, Texas, USA) were used in this study. This field study was conducted at Randolph Farm of Virginia State University located in Ettrick, Virginia. These cultivars were planted in four-row plots with row spacings of 37.5 and $75 \mathrm{~cm}$ in an Abel Sandy Loam soil. Sesame was planted on May 23 and June 8 during 2011 and on July 9 and July 17 during 2012 using a split-split-plot experimental design with planting dates as main plots, row spacings as sub-plots and cultivars as sub-sub-plots with four replications of a Randomized Complete Block Design. The soil received a pre-plant incorporated application of approximately 2 liters of trifluralin herbicide per hectare. The seed was planted in $3 \mathrm{~m}$ long, flat bed plots at a seeding rate of approximately $3 \mathrm{kgha}^{-1}$. Seeding was accomplished using a four-row research planter. The experimental area did not receive any irrigation. The experimental area received a fertilizer application of $112 \mathrm{kgha}^{-1}$ each of $\mathrm{N}, \mathrm{P}$, and $\mathrm{K}$. All plots were harvested manually at maturity, generally in November to December of each year.

\subsection{Determination of Contents of Protein and Minerals in Whole Sesame Seeds}

Chemical composition of sesame seeds were determined by a commercial laboratory (A\&L Agricultural Laboratory, Richmond, VA) according to AOAC standard methods (AOAC, 1995). Protein content was calculated as $\mathrm{N} \times 6.25$.

\subsection{Statistical Analysis}

All data were analyzed using the Analysis of Variance procedures in version 9.3 of SAS (SAS, 2013). Effects of cultivars and row spacings were analyzed by combining data from both years. However, four planting dates were analyzed separately. The means were compared using Fisher's Protected Least Significant Difference at a 5\% level of significance.

\section{Results and Discussion}

Analysis of variance (Table 1) indicated that effects of cultivars and row spacings on seed yield and contents of protein and minerals were, generally, non-significant. Cultivar effects were significant only for content of $\mathrm{P}$ whereas row spacing effects were significant only for seed yield and content of Ca. Otherwise, effects of planting dates were significant for most traits under study except for contents of Fe and Al. Most of the interactions were also non-significant. Contents (averaged over two years, five cultivars, two row spacing, four planting dates, and two years) of protein (\%), P (\%), K (\%), S (\%), Ca (\%), $\mathrm{Mg}(\%), \mathrm{Na}(\%), \mathrm{Fe}\left(\mathrm{mgkg}^{-1}\right), \mathrm{Al}$

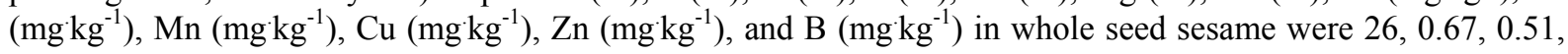
$0.32,1.12,0.33,0.02,110,24,29,17,68$, and 13 , respectively. 
Table 1. Partial analysis of variance (Mean squares) for seed yield and mineral composition in seeds of five sesame cultivars grown using two planting dates and two row spacings in Virginia during 2011 and 2012

\begin{tabular}{ccccccc}
\hline Trait/Source & $\mathrm{C}^{\mathrm{a}}$ & $\mathrm{PD}^{\mathrm{a}}$ & $\mathrm{RS}^{\mathrm{a}}$ & $\mathrm{CxPD}$ & $\mathrm{CxRS}$ & $\mathrm{PDxRS}$ \\
\hline Seed yield (Kg/ha) & $\mathrm{ns}$ & $* *$ & $* *$ & $\mathrm{~ns}$ & $\mathrm{~ns}$ & $*$ \\
Protein & $\mathrm{ns}$ & $* *$ & $\mathrm{~ns}$ & $\mathrm{~ns}$ & $\mathrm{~ns}$ & $\mathrm{~ns}$ \\
$\mathrm{P}^{\mathrm{x}}$ & $*$ & $* *$ & $\mathrm{~ns}$ & $\mathrm{~ns}$ & $\mathrm{~ns}$ & $* *$ \\
$\mathrm{~K}^{\mathrm{x}}$ & $\mathrm{ns}$ & $* *$ & $\mathrm{~ns}$ & $\mathrm{~ns}$ & $\mathrm{~ns}$ & $* *$ \\
$\mathrm{~S}^{\mathrm{x}}$ & $\mathrm{ns}$ & $* *$ & $\mathrm{~ns}$ & $\mathrm{~ns}$ & $\mathrm{~ns}$ & $\mathrm{~ns}$ \\
$\mathrm{Ca}^{\mathrm{x}}$ & $\mathrm{ns}$ & $* *$ & $* *$ & $\mathrm{~ns}$ & $\mathrm{~ns}$ & $\mathrm{~ns}$ \\
$\mathrm{Mg}^{\mathrm{x}}$ & $\mathrm{ns}$ & $* *$ & $\mathrm{~ns}$ & $\mathrm{~ns}$ & $\mathrm{~ns}$ & $* *$ \\
$\mathrm{Na}^{\mathrm{x}}$ & $\mathrm{ns}$ & $* *$ & $\mathrm{~ns}$ & $\mathrm{~ns}$ & $\mathrm{~ns}$ & $\mathrm{~ns}$ \\
$\mathrm{Fe}^{\mathrm{y}}$ & $\mathrm{ns}$ & $\mathrm{ns}$ & $\mathrm{ns}$ & $\mathrm{ns}$ & $\mathrm{ns}$ & $\mathrm{ns}$ \\
$\mathrm{Al}^{\mathrm{y}}$ & $\mathrm{ns}$ & $\mathrm{ns}$ & $\mathrm{ns}$ & $\mathrm{ns}$ & $\mathrm{ns}$ & $\mathrm{ns}$ \\
$\mathrm{Mn}^{\mathrm{y}}$ & $\mathrm{ns}$ & $* *$ & $\mathrm{~ns}$ & $\mathrm{~ns}$ & $\mathrm{~ns}$ & $\mathrm{~ns}$ \\
$\mathrm{Cu}^{\mathrm{y}}$ & $\mathrm{ns}$ & $* *$ & $\mathrm{~ns}$ & $\mathrm{~ns}$ & $\mathrm{~ns}$ & $\mathrm{~ns}$ \\
$\mathrm{Zn}^{\mathrm{y}}$ & $\mathrm{ns}$ & $* *$ & $\mathrm{~ns}$ & $\mathrm{~ns}$ & $\mathrm{~ns}$ & $\mathrm{~ns}$ \\
$\mathrm{~B}^{\mathrm{y}}$ & $\mathrm{ns}$ & $* *$ & $\mathrm{~ns}$ & $\mathrm{~ns}$ & $\mathrm{~ns}$ & $\mathrm{~ns}$ \\
\hline
\end{tabular}

a: C: Cultivars; PD: Planting dates; RS: Row spacings;

*, **: Mean squares significantly different from residual mean squares at 5 and $1 \%$ levels, respectively. ns: not significant;

$\mathrm{x}$ : Protein, $\mathrm{P}, \mathrm{K}, \mathrm{S}, \mathrm{Ca}, \mathrm{Mg}$, and $\mathrm{Na}$ as percent dry weight basis;

$\mathrm{y}: \mathrm{Fe}, \mathrm{Al}, \mathrm{Mn}, \mathrm{Cu}, \mathrm{Zn}$, and B as $\mathrm{mg} \mathrm{kg}^{-1}$ dry weight basis.

Planting date effects on contents of protein, $\mathrm{P}, \mathrm{K}, \mathrm{S}, \mathrm{Ca}, \mathrm{Mg}, \mathrm{Na}, \mathrm{Mn}, \mathrm{Cu}, \mathrm{Zn}$, and $\mathrm{B}$ were significant. Earlier planting during 2011 resulted in significantly higher contents of protein, $\mathrm{P}, \mathrm{K}, \mathrm{S}, \mathrm{Ca}, \mathrm{Mg}, \mathrm{Na}, \mathrm{Mn}, \mathrm{Cu}, \mathrm{Zn}$, and $\mathrm{B}$ whereas contents of these minerals during 2012 were either superior or equal to those from late planting (Table 2). Based on these results, composition of sesame seed could be manipulated based on planting date. Micronutrients are essential elements needed in small amounts for adequate human nutrition and include the elements iron and zinc. Both of these minerals are essential to human well-being and an adequate supply of iron and zinc help to prevent iron deficiency anemia and zinc deficiency, two prevalent health concerns of the developing world (Blair et al., 2009). Zinc content in sesame seed, in our studies, was 20\% higher from earlier planting in 2011 ( 84 vs. $70 \mathrm{mg} \mathrm{kg}^{-1}$. Iron content, in our studies, did not differ due to planting dates. Protein availability in developing countries at present is about one-third of its normal requirements and with ever growing human population; various nutritional development programs are facing a tough challenge to meet the targeted protein demand (Saxena et al., 2010). Protein content, in our studies, was 12.5\% greater from earlier planting (27 vs. 24\% during 2011) as compared to late planting. Based on our results, earlier plantings of sesame are desirable for protein and mineral content. 
Table 2. Effects of planting dates on seed yield and mineral composition in seeds of five sesame cultivars grown using two planting dates and two row spacings in Virginia during 2011 and 2012

\begin{tabular}{ccccc}
\hline Planting date/Trait & May 23, 2011 & June 8, 2011 & July 9, 2012 & July 17, 2012 \\
\hline Seed yield (Kg/ha) & $1427 \mathrm{a}$ & $985 \mathrm{~b}$ & $1697 \mathrm{a}$ & $1017 \mathrm{~b}$ \\
Protein & $27 \mathrm{a}$ & $24 \mathrm{c}$ & $25 \mathrm{~b}$ & $26 \mathrm{~b}$ \\
$\mathrm{P}^{\mathrm{x}}$ & $0.74 \mathrm{a}$ & $0.58 \mathrm{c}$ & $0.67 \mathrm{~b}$ & $0.69 \mathrm{~b}$ \\
$\mathrm{~K}^{\mathrm{x}}$ & $0.57 \mathrm{a}$ & $0.54 \mathrm{~b}$ & $0.47 \mathrm{c}$ & $0.47 \mathrm{c}$ \\
$\mathrm{S}^{\mathrm{x}}$ & $0.35 \mathrm{a}$ & $0.31 \mathrm{c}$ & $0.31 \mathrm{c}$ & $0.32 \mathrm{~b}$ \\
$\mathrm{Ca}^{\mathrm{x}}$ & $1.31 \mathrm{a}$ & $1.11 \mathrm{~b}$ & $1.01 \mathrm{c}$ & $1.06 \mathrm{bc}$ \\
$\mathrm{Mg}^{\mathrm{x}}$ & $0.37 \mathrm{a}$ & $0.30 \mathrm{c}$ & $0.32 \mathrm{~b}$ & $0.33 \mathrm{~b}$ \\
$\mathrm{Na}^{\mathrm{x}}$ & $0.03 \mathrm{a}$ & $0.02 \mathrm{a}$ & $0.02 \mathrm{~b}$ & $0.02 \mathrm{~b}$ \\
$\mathrm{Fe}^{\mathrm{y}}$ & $116 \mathrm{a}$ & $121 \mathrm{a}$ & $102 \mathrm{a}$ & $101 \mathrm{a}$ \\
$\mathrm{Al}^{\mathrm{y}}$ & $19 \mathrm{a}$ & $24 \mathrm{a}$ & $17 \mathrm{a}$ & $37 \mathrm{a}$ \\
$\mathrm{Mn}^{\mathrm{y}}$ & $27 \mathrm{~b}$ & $43 \mathrm{a}$ & $27 \mathrm{~b}$ & $20 \mathrm{~b}$ \\
$\mathrm{Cu}^{\mathrm{y}}$ & $22 \mathrm{a}$ & $20 \mathrm{~b}$ & $13 \mathrm{~d}$ & $14 \mathrm{c}$ \\
$\mathrm{Zn}^{\mathrm{y}}$ & $84 \mathrm{a}$ & $70 \mathrm{~b}$ & $60 \mathrm{c}$ & $60 \mathrm{c}$ \\
$\mathrm{B}^{\mathrm{y}}$ & $15 \mathrm{a}$ & $12 \mathrm{~b}$ & $12 \mathrm{~b}$ & $12 \mathrm{~b}$ \\
\hline
\end{tabular}

$\mathrm{x}$ : Protein, $\mathrm{P}, \mathrm{K}, \mathrm{S}, \mathrm{Ca}, \mathrm{Mg}$, and $\mathrm{Na}$ as percent dry weight basis;

$\mathrm{y}: \mathrm{Fe}, \mathrm{Al}, \mathrm{Mn}, \mathrm{Cu}, \mathrm{Zn}$, and $\mathrm{B}$ as $\mathrm{mg} \cdot \mathrm{kg}^{-1}$ dry weight basis;

*: Means within rows followed by similar letters were not different according to LSD at $5 \%$ level.

Our results indicate that sesame could be planted using either 37.5 or $75 \mathrm{~cm}$ between rows. Contents of protein and minerals were similar from both row spacings except for Ca content (Table 3). Closer row spacing of 37.5 $\mathrm{cm}$ resulted in a seven percent increase in Ca content. With regards to identifying an optimal row spacing for sesame production in Virginia as related to protein and various mineral content in whole sesame seed, our results indicate that either a closer row spacing ( $37.5 \mathrm{~cm}$ between rows) or a wider row spacing ( $75 \mathrm{~cm}$ between rows) could be used. Our objectives were to identify optimal row spacing for sesame production in Virginia because farmers, generally, resist purchase of new equipment when initially evaluating production of new, non-traditional crops. Most Virginia farmers own soybean planters either configured for $37.5 \mathrm{~cm}$ or $75 \mathrm{~cm}$ rows, therefore, sesame in Virginia could be planted with existing planters. Given that amount of seed for planting is small, it might be desirable to use $37.5 \mathrm{~cm}$ rows due to improved weed control from shading. However, if sesame is to be produced organically via cultivation than $75 \mathrm{~cm}$ rows might be desirable. 
Table 3. Row spacing effects on seed yield and mineral composition in seeds of five sesame cultivars grown using two planting dates and two row spacings in Virginia during 2011 and 2012

\begin{tabular}{ccc}
\hline Variable & $37.5 \mathrm{~cm}$ & $75 \mathrm{~cm}$ \\
\hline Seed yield (Kg/ha) & $1478 \mathrm{a}$ & $1086 \mathrm{~b}$ \\
Protein $^{\mathrm{x}}$ & $25 \mathrm{a}$ & $26 \mathrm{a}$ \\
$\mathrm{P}^{\mathrm{x}}$ & $0.67 \mathrm{a}$ & $0.67 \mathrm{a}$ \\
$\mathrm{K}^{\mathrm{x}}$ & $0.51 \mathrm{a}$ & $0.51 \mathrm{a}$ \\
$\mathrm{S}^{\mathrm{x}}$ & $0.32 \mathrm{a}$ & $0.32 \mathrm{a}$ \\
$\mathrm{Ca}^{\mathrm{x}}$ & $1.16 \mathrm{a}$ & $1,08 \mathrm{~b}$ \\
$\mathrm{Mg}^{\mathrm{x}}$ & $.33 \mathrm{a}$ & $0.33 \mathrm{a}$ \\
$\mathrm{Na}^{\mathrm{x}}$ & $0.02 \mathrm{a}$ & $0.02 \mathrm{a}$ \\
$\mathrm{Fe}^{\mathrm{y}}$ & $111 \mathrm{a}$ & $109 \mathrm{a}$ \\
$\mathrm{Al}^{\mathrm{y}}$ & $33 \mathrm{a}$ & $15 \mathrm{a}$ \\
$\mathrm{Mn}^{\mathrm{y}}$ & $29 \mathrm{a}$ & $30 \mathrm{a}$ \\
$\mathrm{Cu}^{\mathrm{y}}$ & $17 \mathrm{a}$ & $17 \mathrm{a}$ \\
$\mathrm{Zn}^{\mathrm{y}}$ & $67 \mathrm{a}$ & $69 \mathrm{a}$ \\
$\mathrm{B}^{\mathrm{y}}$ & $13 \mathrm{a}$ & $13 \mathrm{a}$
\end{tabular}

$\mathrm{x}$ : Protein, $\mathrm{P}, \mathrm{K}, \mathrm{S}, \mathrm{Ca}, \mathrm{Mg}$, and $\mathrm{Na}$ as percent dry weight basis;

y: $\mathrm{Fe}, \mathrm{Al}, \mathrm{Mn}, \mathrm{Cu}, \mathrm{Zn}$, and $\mathrm{B}$ as $\mathrm{mg} \cdot \mathrm{kg}^{-1}$ dry weight basis;

*: Means within rows followed by similar letters were not different according to LSD at 5\% level.

Use of a limited number of cultivars in this study may have resulted in limited effects on protein and mineral content in whole sesame seed. However, most of the worldwide sesame production is based on use of traditional cultivars that are tall and are shattering types (Langham \& Wiemers, 2002). Shattering of sesame capsules in traditional cultivars is not conducive to mechanical harvesting. Sesaco, a private company based in Texas (USA), has been breeding sesame to develop dwarf and shatter-resistant sesame cultivars for several years and released the first dwarf and shatter-resistant sesame cultivar in 1982 (Langham \& Wiemers, 2002). In 2010, Sesaco had more than 100,000 acres of sesame under contract production with growers in southwest Kansas, Oklahoma and central Texas. All dwarf and shatter-resistant sesame cultivars from Sesaco are proprietary. We expect that inclusion of a wider number of sesame cultivars in studies like this would indicate an expanded range of protein and mineral content in sesame seeds. 
Table 4. Cultivar differences for seed yield and mineral composition in seeds of five sesame cultivars grown using two planting dates and two row spacings in Virginia during 2011 and 2012

\begin{tabular}{cccccc}
\hline Variable & $22 \mathrm{~K}$ & $\mathrm{~S} 26$ & $\mathrm{~S} 28$ & $\mathrm{~S} 30$ & $\mathrm{~S} 32$ \\
\hline Seed yield (Kg/ha) & $1147 \mathrm{a}$ & $1232 \mathrm{a}$ & $1171 \mathrm{a}$ & $1436 \mathrm{a}$ & $1424 \mathrm{a}$ \\
Protein $^{\mathrm{x}}$ & $25 \mathrm{a}$ & $25 \mathrm{a}$ & $26 \mathrm{a}$ & $25 \mathrm{a}$ & $26 \mathrm{a}$ \\
$\mathrm{P}^{\mathrm{x}}$ & $0.64 \mathrm{a}$ & $0.67 \mathrm{a}$ & $0.69 \mathrm{a}$ & $0.66 \mathrm{a}$ & $0.68 \mathrm{a}$ \\
$\mathrm{K}^{\mathrm{x}}$ & $0.50 \mathrm{a}$ & $0.50 \mathrm{a}$ & $0.53 \mathrm{a}$ & $0.50 \mathrm{a}$ & $0.52 \mathrm{a}$ \\
$\mathrm{S}^{\mathrm{x}}$ & $0.32 \mathrm{a}$ & $0.32 \mathrm{a}$ & $0.33 \mathrm{a}$ & $0.32 \mathrm{a}$ & $0.33 \mathrm{a}$ \\
$\mathrm{Ca}^{\mathrm{x}}$ & $1.10 \mathrm{a}$ & $1.10 \mathrm{a}$ & $1.14 \mathrm{a}$ & $1.15 \mathrm{a}$ & $1.11 \mathrm{a}$ \\
$\mathrm{Mg}^{\mathrm{x}}$ & $0.31 \mathrm{a}$ & $0.33 \mathrm{a}$ & $0.34 \mathrm{a}$ & $0.32 \mathrm{a}$ & $0.33 \mathrm{a}$ \\
$\mathrm{Na}^{\mathrm{x}}$ & $0.02 \mathrm{a}$ & $0.02 \mathrm{a}$ & $0.02 \mathrm{a}$ & $0.02 \mathrm{a}$ & $0.02 \mathrm{a}$ \\
$\mathrm{Fe}^{\mathrm{y}}$ & $108 \mathrm{a}$ & $107 \mathrm{a}$ & $114 \mathrm{a}$ & $111 \mathrm{a}$ & $109 \mathrm{a}$ \\
$\mathrm{Al}^{\mathrm{y}}$ & $18 \mathrm{a}$ & $19 \mathrm{a}$ & $16 \mathrm{a}$ & $19 \mathrm{a}$ & $49 \mathrm{a}$ \\
$\mathrm{Mn}^{\mathrm{y}}$ & $33 \mathrm{a}$ & $27 \mathrm{a}$ & $31 \mathrm{a}$ & $30 \mathrm{a}$ & $26 \mathrm{a}$ \\
$\mathrm{Cu}^{\mathrm{y}}$ & $18 \mathrm{a}$ & $16 \mathrm{a}$ & $17 \mathrm{a}$ & $18 \mathrm{a}$ & $17 \mathrm{a}$ \\
$\mathrm{Zn}^{\mathrm{y}}$ & $65 \mathrm{a}$ & $66 \mathrm{a}$ & $70 \mathrm{a}$ & $67 \mathrm{a}$ & $71 \mathrm{a}$ \\
$\mathrm{B}^{\mathrm{y}}$ & $13 \mathrm{a}$ & $13 \mathrm{a}$ & $13 \mathrm{a}$ & $13 \mathrm{a}$ & $13 \mathrm{a}$ \\
\hline
\end{tabular}

$\mathrm{x}$ : Protein, $\mathrm{P}, \mathrm{K}, \mathrm{S}, \mathrm{Ca}, \mathrm{Mg}$, and $\mathrm{Na}$ as percent dry weight basis;

$\mathrm{y}: \mathrm{Fe}, \mathrm{Al}, \mathrm{Mn}, \mathrm{Cu}, \mathrm{Zn}$, and $\mathrm{B}$ as $\mathrm{mg} \cdot \mathrm{kg}^{-1}$ dry weight basis;

*: Means within rows followed by similar letters were not different according to LSD at $5 \%$ level.

Our results indicate that effects of cultivars and row spacings on seed yield were non-significant. Seed yield averaged $1282 \mathrm{kgha}^{-1}$. During both years, earlier planting date (1427 vs. $985 \mathrm{kgha}^{-1}$ during 2011 and $1697 \mathrm{vs.}$ $1017 \mathrm{~kg} /$ ha during 2012) resulted in significantly higher seed yield (45\% increase during 2011 and $67 \%$ increase during 2012). Closer row spacing of $37.5 \mathrm{~cm}$ resulted in $37 \%$ more seed yield over wider row spacing of $75 \mathrm{~cm}$ $\left(1478\right.$ vs. $\left.1086 \mathrm{kgha}^{-1}\right)$. These results indicate that earlier plantings using $37.5 \mathrm{~cm}$ inter-row spacings are desirable for commercial sesame production.

\section{Conclusions}

In our studies, planting time significantly affected contents of protein, $\mathrm{P}, \mathrm{K}, \mathrm{S}, \mathrm{Ca}, \mathrm{Mg}, \mathrm{Na}, \mathrm{Mn}, \mathrm{Cu}, \mathrm{Zn}$, and $\mathrm{B}$ in sesame seeds, thus, indicating desirability of early plantings. Our studies also indicated that sesame could be produced in Virginia using either 37.5 or $75 \mathrm{~cm}$ space between rows. Highest seed yields were obtained using closer row spacings and early plantings. Our results indicated, for the first time, that sesame could be easily produced as a commercial crop in Virginia.

\section{Acknowledgements}

Financial support from Virginia Tobacco Commission (Virginia Tobacco Indemnification and Community Revitalization Commission) is gratefully acknowledged. Contribution of Virginia State University, Agricultural Research Station, Journal Article Series number 317. Use of any trade names or vendors does not imply approval to the exclusion of other products or vendors that may also be suitable.

\section{References}

AgMRC. (2013). Sesame Profile. Ag Marketing Resource Center. Iowa State University, Ames, IA. Retrieved June 19, 2014, from http://www.agmrc.org/commodities_products/grains_oilseeds/sesame-profile

AOAC. (1995). Official Methods of Analysis. Association of Official Analytical Chemists. $16^{\text {th }}$ Edition. Arlington, VA 22001. Retrieved June 19, 2014, from http://www.abebooks.com/servlet/BookDetailsPL?bi=12646263720\&searchurl=tn\%3Dofficial\%2Bmethods \%2Banalysis\%2Bassociation\%2Bofficial\%2Banalytical\%2Bchemists

Bhardwaj, H. L., Hamama, A. A., Kraemer, M. E., \& Langham, D. R. (2014). Sugars in whole sesame seed: Effects of cultivars, planting dates, and row spacings. Amer. J. Exp. Agriculture, 4(9), 978-984. 
http://dx.doi.org/10.9734/AJEA/2014/8999

Bhardwaj, H. L., Rangappa, M., \& Hamama, A. A. (1999). Chickpea, faba bean, lupin, mungbean, and pigeonpea: Potential new crops for the Mid-Atlantic Region of the United States. In J. Janick (Ed.), Perspectives on new crops and new uses (pp. 202-205). ASHS Press, Alexandria, VA.

Blade, S. F., \& Slinkard, A. E. (2002). New crop development: The Canadian experience. In J. Janick \& A. Whipkey (Eds.), Trends in New Crops and New Uses (pp. 62-75). ASHS Press, Alexandria, VA. Retrieved June 19, 2014, from http://www.hort.purdue.edu/newcrop/ncnu02/pdf/blade.pdf

Blair, M. W., Astudillo, C., Grusak, M. A., Graham, E. R., \& Beebe, S. E. (2009). Inheritance of iron and zinc concentrations in common bean (Phaseolus vulgaris L.). Molecular Breeding, 23, 197-207. http://dx.doi.org/10.1007/s11032-008-9225-z

CAST. (2003). Diversifying U.S. Crop Production. Council for Agricultural Science and Technology, Ames, IA 50014. Retrieved June 19, 2014, from http://www.cast-science.org/publications/index.cfm?diversifying_us_crop_production\&show=product\&pro ductID $=2844$

Fletcher, R. J. (2002). International new crop development incentives, barriers, processes, and progress: An Australian experience. In J. Janick \& A. Whipkey (Eds.), Trends in New Crops and New Uses (pp. 40-54). ASHS Press, Alexandria, VA. Retrieved June 19, 2014, from http://www.hort.purdue.edu/newcrop/ncnu02/pdf/fletcher.pdf

Langham, D. R., \& Wiemers, T. (2002). Progress in mechanizing sesame in the US through breeding. In J. Janick \& A. Whipkey (Eds.), Trends in New Crops and New Uses (pp. 157-173). ASHS Press, Alexandria, VA. Retrieved June 19, 2014, from http://www.hort.purdue.edu/newcrop/ncnu02/v5-157.html

SAS. (2013). SAS System for Windows. SAS Institute, Inc., Cary, NC. Retrieved from http://www.sas.com/en_us/software/sas9.html

Saxena, K. B., Kumar, R. V., \& Sultana, R. (2010). Quality nutrition through pigeonpea - a review. Health, 2(11), 1335-1344. http://dx.doi.org/10.4236/health.2010.211199

\section{Copyrights}

Copyright for this article is retained by the author(s), with first publication rights granted to the journal.

This is an open-access article distributed under the terms and conditions of the Creative Commons Attribution license (http://creativecommons.org/licenses/by/3.0/). 